\section{Inhibition of Cholinesterase by Dialkylcarbamates}

Šárka Štěpánkováa,*, Karel Komers ${ }^{\mathrm{b}}$, Alena Komersováb, Markéta Masopustováb, and Alexander Čegan ${ }^{\mathrm{a}}$

a Faculty of Chemical Technology, University of Pardubice, Department of Biological and Biochemical Sciences, Strossova 239, 53003 Pardubice, Czech Republic.

Fax: (0042046) 6037068 .

E-mail: sarka.stepankova@upce.cz

b Faculty of Chemical Technology, University of Pardubice, Department of Physical Chemistry, nám Čs. legií 565, 53210 Pardubice, Czech Republic

* Author for correspondence and reprint requests

Z. Naturforsch. 62 c, 308-310 (2007); received October 2/ November 24, 2006

The $\mathrm{p}_{50}$ index and separation coefficients of chosen 3-N,N-diethylaminophenyl- $N^{\prime}, N^{\prime}$-dialkylcarbamates were determined. Index $\mathrm{p}_{50}\left(\mathrm{p} I_{50}=\right.$ negative logarithm of molar concentration of inhibitor inhibiting the enzyme activity by $50 \%$ ) describes the effectiveness of the inhibitor. The rate of ability of the inhibitor to pass the blood-brain barrier is usually described by the separation coefficient in a system $n$-octanol/water $\left(K_{\text {ow }}\right)$. Obtained results were compared with $\mathrm{p} I_{50}$ and $K_{\mathrm{ow}}$ of Exelon ${ }^{\circledR}$, the commercially used drug against the Alzheimer's disease.

Key words: Cholinesterase Inhibitors, $\mathrm{p} I_{50}, K_{\text {ow }}$

\section{Introduction}

Our research group studies carbamate inhibitors of cholinesterases since several years. In our earlier works we were engaged in monoalkylcarbamates (Zdražilová et al., 2004, 2006). This work is focused on dialkylcarbamates.

The aim of our research is to find a suitable inhibitor decreasing the activity of acetylcholinesterase (ACHE) and butyrylcholinesterase (BCHE) and to compare its inhibiting power (described by the index $\mathrm{p} I_{50}$ ) and separation coefficient with the drug against Alzheimer's disease (AD) - Exelon ${ }^{\circledR}$.

Acetylcholine acts as a neuromediator of the cholinergic nerve system in the human brain. The decreased amount of acetylcholine is considered to be one of the most common reasons for AD (Scheibel et al., 1986).

Acetylcholine is hydrolyzed by several forms of cholinesterases, which can be inhibited by various inhibitors. Carbamates belong to the most important cholinesterase inhibitors. They are synthetic analogues of acetylcholine. The inhibition effect of carbamates is based on their ability to react with the reaction centre of acetylcholinesterase, which is formed by the hydroxy group of serine. These inhibitors block physiological functions of ACHE by carbamoylation of the serine hydroxy group (Booth and Metcalf, 1970).

\section{Experimental}

\section{Chemicals}

Dioxane p. a., $\mathrm{KH}_{2} \mathrm{PO}_{4}$ p. a., $\mathrm{Na}_{2} \mathrm{HPO}_{4} \cdot 12 \mathrm{H}_{2} \mathrm{O}$ were all from Lachema, Brno, CZ.

Acetylthiocholine iodide p. a. (substrate) was kept at $5{ }^{\circ} \mathrm{C}$. From this substance the analytical aqueous solution $(0.225 \mathrm{~mm})$ was prepared for daily experiments and kept at $5{ }^{\circ} \mathrm{C}$. Acetylcholinesterase: ACHE1, lyophilisate from electric eel; ACHE2, lyophilisate from bovine erythrocytes. Butyrylcholinesterase: $\mathrm{BCHE}$, lyophilisate from equin serum. All enzymes were kept at $-6^{\circ} \mathrm{C}$. A suitable amount of every enzyme preparation was dissolved in demineralized water (the enzymatic activity of these solutions was $0.25 \mathrm{U} / \mathrm{ml}$ ). This solution was divided into suitable aliquots which were kept frozen at $-6{ }^{\circ} \mathrm{C}$. For the daily experiments a portion was melted and kept at $5{ }^{\circ} \mathrm{C}$.

5,5'-Dithiobis-2-nitrobenzoic acid (DTNB, Ellman's reagent) was kept at $5^{\circ} \mathrm{C}$. From this substance the analytical aqueous solution $(0.21 \mathrm{~mm})$ was prepared and kept at $5{ }^{\circ} \mathrm{C}$. Substrate, enzymes and Ellman's reagent were obtained from SigmaAldrich, Praha, CZ. The used inhibitors (Table I) were synthesized in the Department of Organic Chemistry, Faculty of Chemical Technology, University of Pardubice, Czech Republic. All inhibitors were kept at $5{ }^{\circ} \mathrm{C}$. Inhibitors were first solved to $0.05 \mathrm{M}$ solutions in dioxane and then diluted to smaller concentrations by demineralized water.

\section{Method and apparatus}

Determination of the index $\mathrm{p} I_{50}$

Into the test tubes $0.1,0.2,0.3,0.4$ and $0.5 \mathrm{ml}$ of $5 \mathrm{~mm}, 0.5 \mathrm{~mm}, 0.05 \mathrm{~mm}$ and $5 \mu \mathrm{M}$ solution of the tested inhibitors I-IV (Table I) were placed. All solutions were filled to the volume of $1 \mathrm{ml}$ with phosphate buffer, $\mathrm{pH}$ 7.6. One test tube contained 


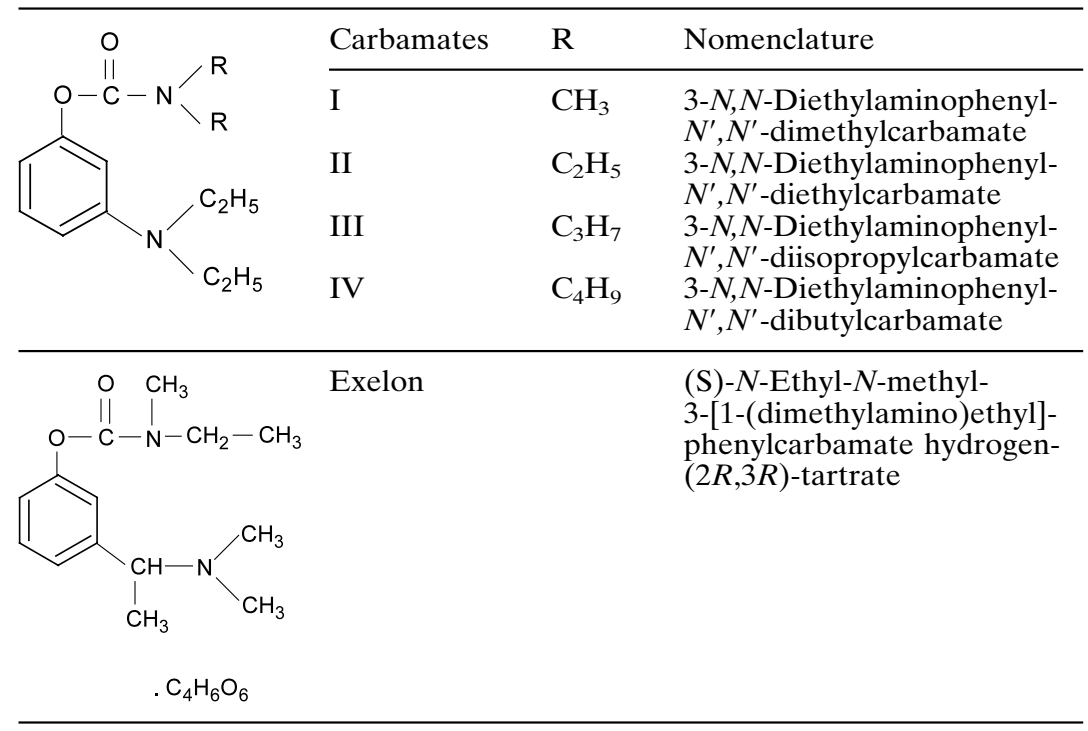

Table I. An overview of used inhibitors.

only $1 \mathrm{ml}$ of phosphate buffer, $\mathrm{pH}$ 7. 6. Then $0.5 \mathrm{ml}$ of enzyme preparation (ACHE1, ACHE2 or $\mathrm{BCHE}$ ) was added into all test tubes. Mixtures were quickly homogenized and then thermostated $5 \mathrm{~min}$ at $25^{\circ} \mathrm{C}$. Then $0.25 \mathrm{ml}$ of acetylthiocholine $(0.225 \mathrm{~mm})$ and $0.25 \mathrm{ml}$ of DTNB $(0.21 \mathrm{~mm})$ were added into all test tubes. Mixtures were quickly homogenized again and thermostated $10 \mathrm{~min}$ at $25^{\circ} \mathrm{C}$. Absorbance $A$ (at $412 \mathrm{~nm}$ ) of all mixtures was measured and compared with a comparative solution $(1 \mathrm{ml}$ of phosphate buffer, $\mathrm{pH} 7.6,0.5 \mathrm{ml}$ of demineralized water, $0.25 \mathrm{ml}$ of $0.225 \mathrm{~mm}$ acetylthiocholine and $0.25 \mathrm{ml}$ of $0.21 \mathrm{~mm}$ DTNB). From the dependence inhibition of enzyme preparation in percent $(\% I)$ [calculated according to (1)] vs. p $I(=-\log [I])$ the value of the index $\mathrm{p} I_{50}$ was determined graphically:

$$
\% I=\left(1-\frac{A_{\mathrm{i}}}{A_{0}}\right) * 100,
$$

where $A_{\mathrm{i}}$ is the absorbance of solution with inhibitor and $A_{0}$ is the absorbance of solution without inhibitor.

Determination of the separation coefficient $\left(K_{\text {ow }}\right)$ in the system $n$-octanol/water

Into the test tube $1.5 \mathrm{ml}$ of $n$-octanol were placed. Then $10 \mu \mathrm{l}$ of octanol solution of the chosen inhibitor $(0.05 \mathrm{M})$ were added. Mixture was intensively shaken for $15 \mathrm{~min} .1 \mathrm{ml}$ of this mixture was placed into the cuvette and its absorbance at the wave- length of absorption maximum was measured. Comparative solution was $n$-octanol. The value of absorbance which corresponds to $100 \%$ of chosen inhibitor in $n$-octanol was obtained.

$10 \mu \mathrm{l}$ of octanol solution of chosen inhibitor $(0.05 \mathrm{M})$ were added into the mixture of $n$-octanol $(1.5 \mathrm{ml})$ and demineralized water $(1.5 \mathrm{ml})$. Mixture was intensively shaken for $15 \mathrm{~min}$ and then centrifuged (3000 rpm, $10 \mathrm{~min}$ ). $1 \mathrm{ml}$ of the octanol layer was put into the cuvette and its absorbance at the wavelength of absorption maximum was measured. Comparative solution was $n$-octanol again. Percentage content of the chosen inhibitor in the octanol layer $(\%)_{1}$ was obtained. Then the percentage content of inhibitor in the water layer was calculated $\left[100-(\%)_{1}\right]$. Separation coefficients were calculated according to

$$
K_{\mathrm{ow}}=\frac{(\%)_{1}}{100-(\%)_{1}}=\frac{c_{1}}{c_{2}},
$$

where $c_{1}$ and $c_{2}$ are molar concentrations of the chosen inhibitor in $n$-octanol and water.

\section{Results and Discussion}

In Table II the values of the index $\mathrm{p} I_{50}$ and separation coefficients $K_{\mathrm{ow}}$ of the tested inhibitors are presented.

From the obtained results we can formulate the following conclusions: 


\begin{tabular}{lcccc}
\hline Inhibitor & $\mathrm{p} I_{50}(\mathrm{ACHE} 1)$ & $\mathrm{p} I_{50}(\mathrm{ACHE} 2)$ & $\mathrm{p} I_{50}(\mathrm{BCHE})$ & $K_{\mathrm{ow}}$ \\
\hline $\mathrm{I}$ & 4.61 & 4.22 & 5.74 & 3.12 \\
II & 4.05 & 3.13 & 6.44 & 1.87 \\
III & 4.13 & 3.35 & 4.84 & 0.86 \\
IV & 4.76 & 3.65 & 4.92 & 0.98 \\
Exelon $^{\circledR}$ & 3.26 & 4.15 & 4.75 & 0.09 \\
\hline
\end{tabular}

Table II. The determined values of index $\mathrm{p} I_{50}$ and separation coefficients of tested inhibitors.
1. All tested substances are at least the same effective inhibitors as the used drug against Alzheimer's disease - Exelon ${ }^{\circledR}$.

2. Substitution by a longer alkyl group on the $\mathrm{N}$ atom hasn't a uniform influence on the value of the index $\mathrm{p} I_{50}$.

3. The most effective inhibitor of ACHE1 is inhibitor IV, of ACHE2 inhibitor I and of $\mathrm{BCHE}$ inhibitor II.

4. Generally it is possible to conclude that inhibition of BCHE by the used inhibitors is stronger than of ACHE1 and ACHE2.

5. In comparison with Exelon ${ }^{\circledR}$ (Zdražilová et al., 2004 , see Table II) the presented index $\mathrm{p}_{50}$ val-

Booth G. M. and Metcalf F. R. L. (1970), Histochemical evidence for localized inhibition of cholinesterase in the house fly. Ann. Entomol. Soc. Am. 63, 197-204.

Scheibel A. B., Wechsler A. F., and Brazier M. A. B. (1986), The Biological Substrates of Alzheimer's Disease. Academic Press, Orlando, FL, USA, pp. 73-80.

Zdražilová P., Štěpánková Š., Komers K., Ventura K., and Čegan A. (2004), Half-inhibition concentrations ues of the tested substances exhibit the same or even better inhibition of the used enzymes in vitro.

6. The values of separation coefficients show a uniform effect. The value of separation coefficient decreases with increasing number of $\mathrm{C}$ atoms of the alkyl group. The exception is only inhibitor III, because its $K_{\text {ow }}$ value is lower than the $K_{\text {ow }}$ value of inhibitor IV.

\section{Acknowledgement}

This work was financially supported by Ministry of Education, Youth and Sport as a part of the research project MSM0021627502.

of cholinesterase inhibitors. Z. Naturforsch. 59c, 293-296.

Zdražilová P., Štěpánková Š., Komersová A., Vránová M., Komers K., and Čegan A. (2006), Kinetics of 13 new cholinesterase inhibitors. Z. Naturforsch. 61c, $611-617$. 